\title{
Protein-lipid interactions at interfaces
}

\author{
By A. Fillery-Travis*, ENC Mills, and P Wilde \\ Institute of Food Research, Norwich Research Park, Norwich NR4 7UA.UK. \\ Correspondence should be sent to Dr A Fillery-Travis at the above address \\ (Tel:44-1603-255000. Fax: 44-1603-507723. \\ E-mail: Annette.Fillery-Travis@BBSRC.AC.UK)
}

\section{RESUMEN}

\section{Interacciones lípido-proteína en interfases}

Las espumas y las emulsiones son dispersiones de una fase inmiscible (ejemplo aire o aceite) en otra (ejemplo agua). Las moléculas anfifílicas (bien proteínas o compuestos químicos) pueden estabilizar la interfase y se denominan emulsionantes. En este artículo se revisa la habilidad de los emulsionantes proteínicos para enlazar lípidos y los mecanismos que subyacen en el comportamiento de estas moléculas así como de los tensioactivos de bajo peso molecular en la interfase. Recientes investigaciones que usan la microscopía han ofrecido visiones nuevas de los mecanismos mediante los cuales las proteínas y los tensioactivos de bajo peso molecular interaccionan cuando ambos están presentes en la interfase, comprometiendo la estabilidad de espumas y emulsiones estabilizadas por estas mezclas. El entendimiento de las interacciones entre componentes a nivel interfacial es esencial para lograr avances en el control y manipulación de alimentos multifases durante la producción y el almacenamiento.

PALABRAS-CLAVE: Alimentos multifase - Física interfacial - Microscopía - Proteínas que enlazan lípidos.

\section{SUMMARY}

\section{Protein-lipid interactions at interfaces}

Foams and emulsions are both types of multiphase foods and are a dispersion of one immiscible phase (e.g. air or oil) in another (e.g. water). Amphiphilic molecules (either proteins or chemical compounds) are able to stabilise the interface between these phases and are termed emulsifiers. The ability of protein emulsifiers to bind lipid is reviewed, and the mechanisms underlying the behaviour of these and low molecular weight surfactants (LMWS) at the interface are summarised. New research, exploiting atomic force microscopy, has given fresh insights into the mechanisms by which proteins and LMWS interact when both are present at the interface, compromising the stability of foams and emulsions stabilised by these mixtures. The understanding of component interactions at the interfacial level is essential if advances are to be made in the control and manipulation of multiphase foods during production and storage.

KEY-WORDS: Atomicforce microscopy - Interfacial physics — Lipid-binding proteins - Multiphase foods.

\section{PROTEIN STABILISED FOAMS AND EMULSIONS}

The texture and organoleptic properties of many foods arise as a consequence of their multiphase nature. Thus they may comprise a liquid and an air phase to form a foam structure, such as is found in bread, cakes, mousses and beers, or a liquid and an oil phase to form an emulsion, such as is found in sauces, gravies, and spreads. Foams and emulsions share a common feature; they are a dispersion of one phase (dispersed phase) in another (continuous phase). The two phases are immiscible and the successful stabilisation of the dispersed phase within the continuum results in very different structural and rheological properties to those of the individual phases. For example, whipping a solution of egg albumin results in a very viscous foam, the textural properties of which are completely different to those of the parent solution or the entrapped air. Molecules that are able to stabilise foams and emulsions must be surface active and form an adsorbed layer at the boundary or interface between the different phases. As a consequence they must possess both hydrophobic and hydrophilic regions within their structure and are, by definition, amphiphilic. The two main classes of amphiphilic molecules used within food dispersions are proteins and low molecular weight surfactants or emulsifiers. This review will focus on the role of proteins in stabilising air-water and oil-water interfaces, and their interactions with lipid at the interface.

\section{THE NATURE OF PROTEIN-LIPID INTERACTIONS}

Native proteins are able to bind lipid in two main ways (Figure 1), either in a cavity or binding, or through less well defined hydrophobic patches which lie close to the surface of the protein. Both types of proteins have been found to be interfacially active. One example from milk is the major whey protein $\beta$-lactoglobulin, which binds a wide variety of aliphatic components in its binding site, including lipids (Perez et al 1992), whilst from cereals the nonspecific lipid transfer proteins (ns LTP) seem to have an important functional role at interfaces, especially with regards beer foam 
A

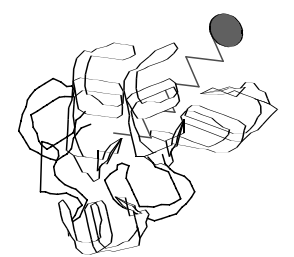

Lipid binds in a pocket (eg. lipid transfer proteins $\beta$-lactoglobulin)

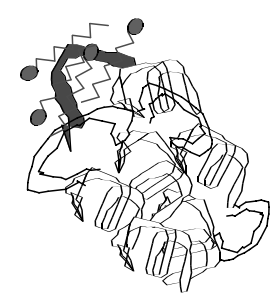

Lipid binds to exposed hydrophobic regions (eg. puroindoline)

Figure 1

Modes of lipid binding in native interfacially active food proteins. A - proteins which bind lipids in a pocket

$B$ - proteins which bind lipid through exposed hydrophobic regions

stability (Sorensen et al 1993) and is known to bind lipids in a central pocket (Poulsen et al). One of the remarkable features of many of the lipid binding sites found in these proteins is their ability to accommodate a wide range of aliphatic molecules, and some mammalian LTPS have been found to bind simple lipids, but also expand in size to accommodate triglycerides (Bruce et al., 1998). An example of a protein with an accessible

hydrophobic lipid binding site are the wheat puroindolines (PINs). Their tryptophan rich regions are able to bind a variety of lipids (Wilde et al., 1993; Kooijman et al., 1997). Despite belonging to the same supergene family as the ns LTPs and sharing a great deal of structural homology, PINs appear to bind lipid by a different mechanism, although this will only be defined once their three dimensional structures have been determined. They also have a functional effect on the stability of air-water interfaces in foods. Thus, the addition of PIN has been found to aid the recovery of beer foam that has been adversely affected by lipid (Clark et al., 1994) possibly by binding residual free lipids in such a way that they no longer cause collapse of the bubble network. The importance of the interfacial properties of PIN in food systems has also been indicated by its effect on the crumb structure of bread (Dubreil et al., 1998).

As well as naturally occurring lipid-binding sites, new binding sites can be induced by processing using heat or pressure, or as a consequence of the $\mathrm{pH}$ and ionic strength of a food system (Figure 2). Thus, the proteins may unfold to reveal the more hydrophobic sites normally only present in the centre of the protein, or the conditions may cause dimeric proteins to dissociate to reveal the hydrophobic faces normally buried in the dimer interface. Such alterations form the basis of the treatments frequently used to the potentiate the functional properties of food protein ingredients.

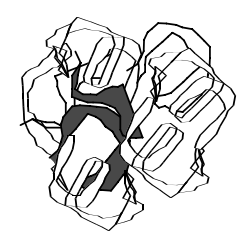

Native protein with hydrophobic residues in the interior

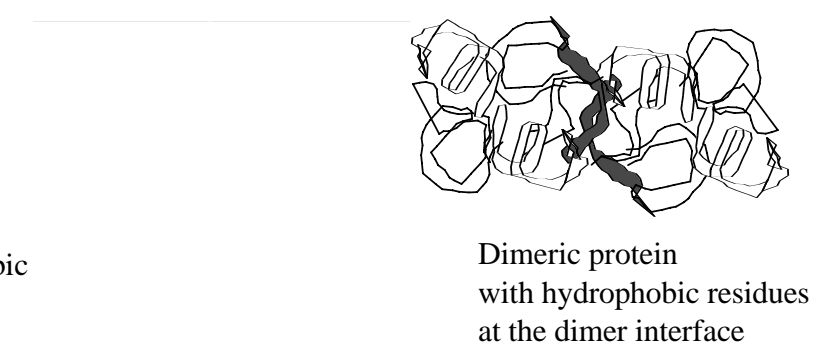

Heat, $\mathrm{pH}$, ionic strength adsorption?

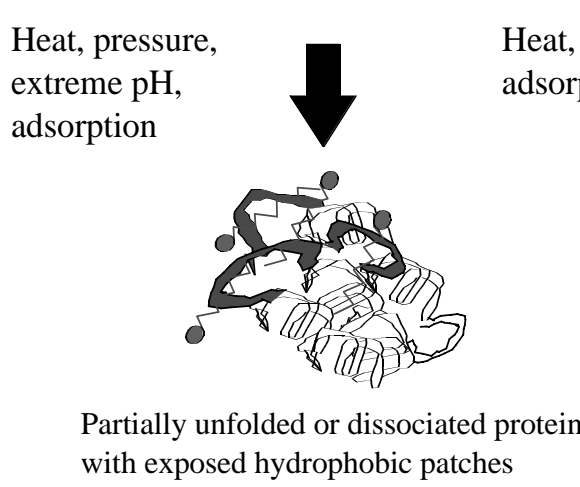

Figure 2

Processes which introduce lipid-binding regions in proteins through dissociation and unfolding of native proteins 


\section{PROTEIN STABILISED INTERFACES}

For a soluble protein to significantly lower the interfacial tension between two phases, it must first undergo a rearrangement of its structure to expose hydrophobic amino acids to the hydrophobic phase (cf Figure 2). Thus, the rate of lowering of the interfacial tension can be very slow compared to emulsifiers or surfactants (Wilde and Clark, 1996). In addition, proteins are larger than surfactants, so their diffusion to the interface is slower. This rate of change in interfacial tension equates directly to the amount of interfacial area created over the short time periods during homogenisation and foam generation. Therefore, proteins are generally less efficient at creating dispersions and the foams and emulsions created by surfactants and emulsifiers tend to have smaller droplet and bubble size distributions for a given energy input.

The mechanism of interfacial stabilisation for proteins and small molecule surfactants also differs considerably (Figure 3). Surfactants or emulsifiers form a very dense, fluid interfacial layer and can reduce the interfacial tension between the two phases to very low values, which corresponds to large increases in surface area. They prevent the dispersion breaking or coalescing by interfacial movement known as the Gibbs-Marangoni mechanism (Figure 3b), which restabilises any interfacial tension gradients which occur. Similarly, proteins adsorb at the interface and lower the interfacial tension enabling dispersion, but to prevent coalescence they unfold at the interface (Figure 3a) and interact with neighbouring proteins through electrostatic, hydrophobic and covalent interactions to form a viscoelastic adsorbed film (MacRitchie, 1978; Dickinson et al., 1990; Krägel et al., 1995). The mechanical strength of the viscoelastic adsorbed layer created by proteins is extremely efficient at preventing coalescence in both foams and emulsions, it is also capable of retarding drainage from foams (Wilde 1996).

\section{PROTEIN-LIPID INTERACTIONS AT THE INTERFACE}

Whilst both proteins and surfactants can both stabilise foams successfully, problems arise when both are present at the surface. The mobility of the surfactants is compromised by the protein and the visco-elasticity of the protein adsorbed layer is reduced by the presence of the surfactant. This often results in coalescence (Coke et al., 1990; Wilde, 1996), a major problem in many food foam systems, but which can also be exploited in the case of antifoaming agents where foam presents a problem during food production. Figure. 4 shows the effect of adding a surfactants to a protein stabilised

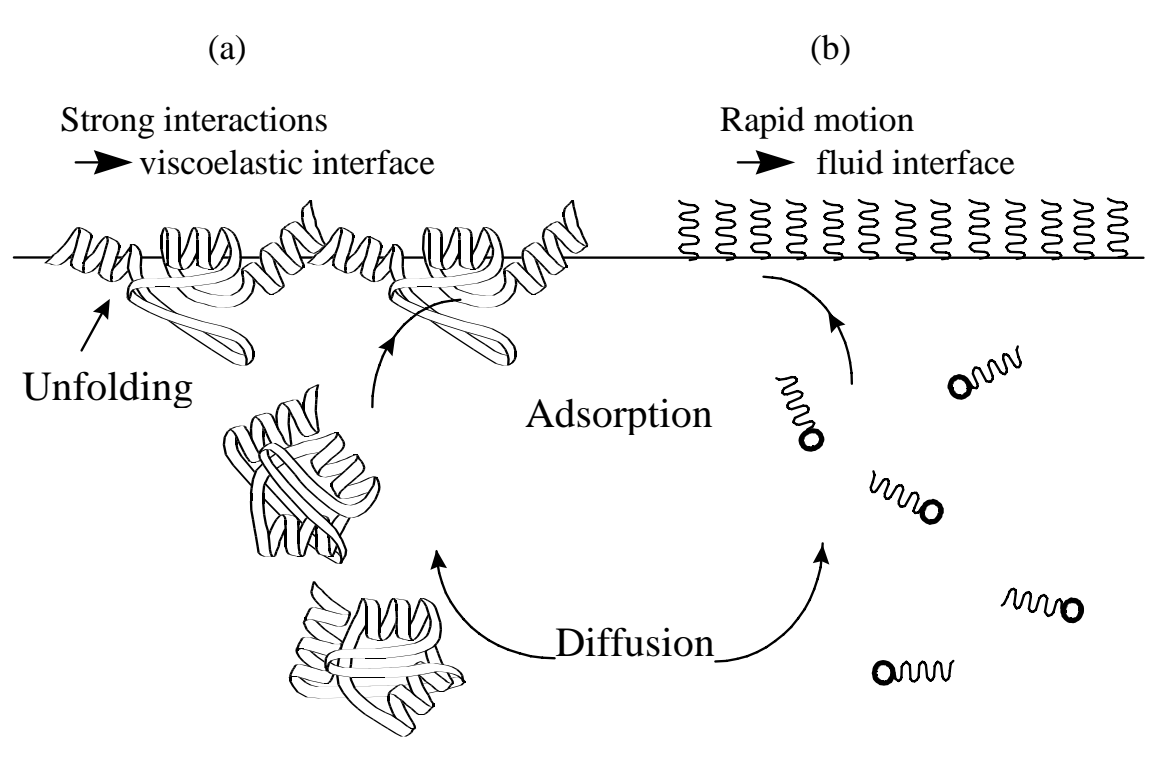

Figure 3

Comparison of the adsorption behaviour of proteins and surfactants.

Both diffuse and adsorb to the interface, but only proteins unfold (surface denaturation), to give a viscoelastic adsorbed layer strengthened by intermolecular interactions 
interface. The shear dependant elasticity of the protein alone shows a long linear region, before at high shear, the surface elasticity is broken down and the interface yields. In the presence of surfactant, the elasticity is reduced, and also the stress at which the surface yields is much lower, demonstrating how the stability of foams and emulsions stabilised by these mixtures can be compromised.

This effect can be visualised by imaging the interface using atomic force microscopy (AFM). This methodology involves adsorbing a protein and/or surfactant to an air/water interface, then transferring a section of the surface onto a mica sheet for measurement by the AFM (Mackie, et al., 1999). The AFM 'feels' the surface of a sample using a piezo crystal driven device, to give a three dimensional map of a surface with very high resolution. Figure 5 shows an AFM image of a mixed protein: surfactant surface, the dark areas represent the surfactant and the light regions denote thicker, protein areas.

It is possible to visualise from Figure 5 how the presence of the surfactant domains has reduced the elasticity of the protein network as demonstrated in Figure 3 . It is also possible to imagine how the mobility of the surfactant is restricted or 'caged', which severely limits the ability of the surfactant to stabilise foam lamellae by the Gibbs-Marangoni mechanism, resulting in poor foam stability due to increased rates of coalescence (Coke et al., 1990; Wilde, 1996). This

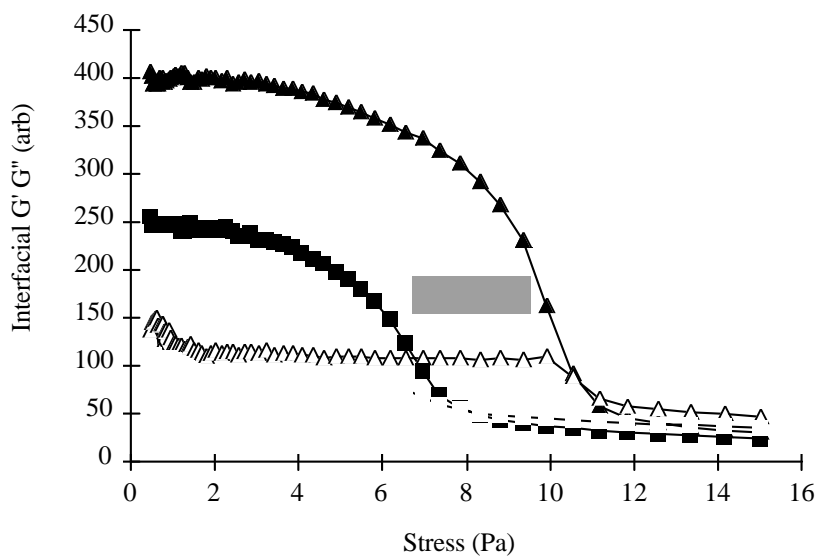

Figure 4

Foam liquid content of free draining foams as a function of time after foam creation.

Curve (a) is a protein (bovine serum albumin) foam and curve (b) is a LMWS (Tween 20) foam. Both solutions had identical densities (999.0 kg.m-3), viscosities (1.01 mPa.s), and average bubble size $(0.71 \mathrm{~mm})$. No coalescence was observed in either foam also indicates how important the critical stress is for foam drainage. Low stress circumstances such as model foam lamellae drainage will display rigid, elastic properties, but higher stress events such as foam drainage and deformation may cause the breakdown of the surface, and lead to a fluid interface, and different drainage behaviour

\section{THE INFLUENCE OF PROTEIN STRUCTURE AND STABILITY ON INTERFACIAL BEHAVIOUR}

The main physicochemical properties which define the ability of a protein to form and stabilise dispersions are size, solubility, hydrophobicity, charge and flexibility. In addition to the effect of size on the rate of adsorption to an interface, a protein must be soluble to be available to adsorb. Insoluble proteins tend to form large aggregates which are incapable of rapid diffusion and adsorption, and result in poor quality dispersions. The hydrophobicity of a protein will also determine the interfacial tension value which changes as the number and density of hydrophobic residues at the interface increases (Toledano and Magdassi, 1998; Watanabe et al., 1981). Increased surface hydrophobicity has also been associated with increased rates of adsorption (Horiuchi et al., 1978). Protein flexibility is another

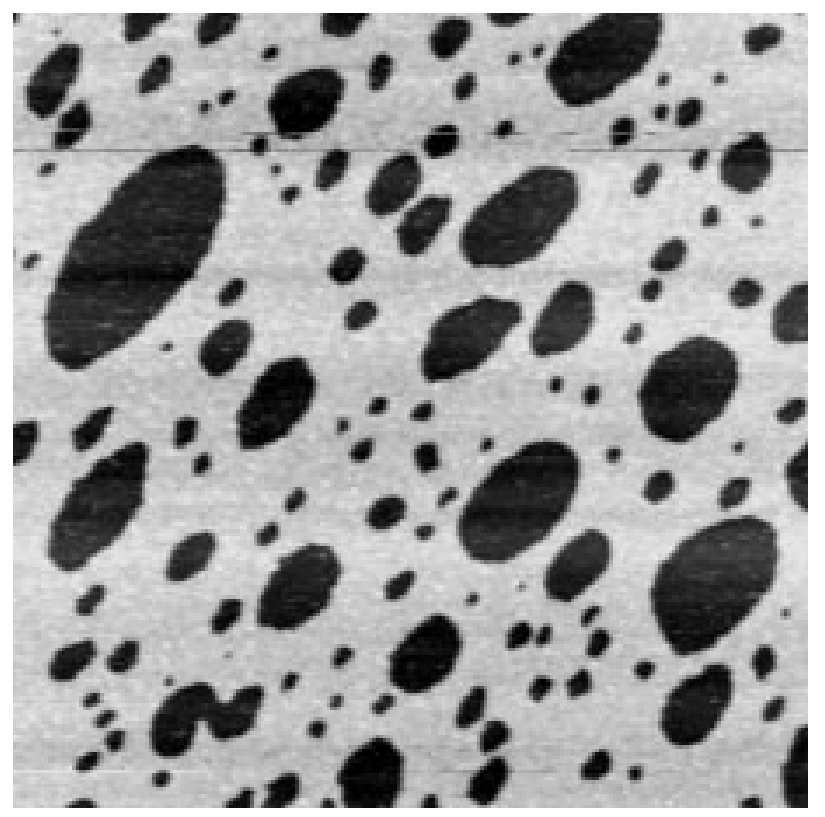

Figure 5

An AFM image of a mixed protein ( $\beta$-casein):surfactant (Tween 20) surface.

The darker regions represent thin, fluid surfactant domains. The light areas represent the thicker, viscoelastic, protein network. Image size $=4 \mu \mathrm{m} \times 4 \mu \mathrm{m}$ 
important factor in protein adsorption (Mitchell, 1986; Townsend and Nakai, 1983) and affects the final number of hydrophobic residues exposed to the surface and the rate of (Closs et al., 1990). For example, $\beta$-casein is a very flexible protein which is able to unfold rapidly at the interface and hence lower the interfacial tension faster than many other proteins (Lorient et al., 1989). Finally charge can affect a proteins' interfacial behaviour in two ways, through interfacial protein-protein interactions, and electrostatic repulsion. The former are noncovalent in nature (comprising of van der Waals forces and $\mathrm{H}$-bonds) and contribute to the overall interfacial viscoelasticity by strengthening the gel layer of protein at the interface. The contribution of charge is highlighted by the observation that surface viscoelasticity reaches a maximum when the $\mathrm{pH}$ is close to a proteins' isoelectric point ie. its net charge is zero (Kim and Kinsella, 1985; Maeda et al., 1991).

The structure of the adsorbed protein can also influence stability of the dispersion through the longer range colloidal forces which prevent aggregation/flocculation. Pair-wise interaction potentials for emulsion or suspension particles consider three major contributions to the interaction; van der Waals attraction, electrostatic repulsion and steric hindrance. By increasing the overall charge on a dispersed phase droplet through the charge of the adsorbed protein the dispersion can be stabilised by the electrostatic repulsion of the droplets hindering their close approach. Reduction of the charge can have drastic effects on dispersion stability (Husband et al., 1997). Similarly, the presence of large hydrophilic loops or tails can provide a steric hindrance to particle encounter.

\section{CONCLUSION}

For many years studies of food systems at the molecular level have, partly out of necessity arising from the limitations of the analytical methodologies, been largely limited to investigating single components within a food system. However, much is lost with such an approach and it is only as the interactions between food components become understood that the functional properties of food systems, so clearly and well characterised at the macro level, can be explained. This review shows how we are applying such an approach to studying the lipid-protein interactions in multiphase food systems and hence defining the role they play in determining the bulk properties of such foods. Only through such endeavours will we be able to develop knowledge-based strategies for improving the utilisation of raw materials and increasing processing efficiency.

\section{REFERENCES}

Bruce C., Beamer, L.J., Tall, A.R. (1998). The implications of the structure of the bacteriacidal/permeability increasing protein on the lipid-transfer function of the cholesteryl ester transfer protein. Current Opinion in Structural Biology 8, 426-434.

Clark, D.C., P.J. Wilde, Marion, D. (1994). The protection of beer foam against lipid-induced destabilisation. Journal of the Institute of Brewing 100, 23-25.

Closs, B., Courthaudon, J.L., Lorient, D. (1990). Effect of glycosylation on the surface properties of the soluble fraction of casein. Journal of Food Science 55, 437-439.

Coke, M., Wilde, P. J., Russell, E. J., Clark, D.C. (1990). The influence of surface composition and molecular diffusion on the stability of foams formed from protein detergent mixtures. Journal of Colloid and Interface Science 138, 489-503.

Dickinson, E., Rolfe, S.E., Dalgleish, D.G. (1990). Surface shear viscometry as a probe of protein-protein interactions in mixed milk protein films adsorbed at the oil water interface. International Journal of Biological Macromolecules, 12, 189-194.

Dubreil, L., Méliande, S., Chiron, H., Compoint, J.-P., Quillien, L., Branlard, G., Marion, D. (1998). Effect of purindolines on the breadmaking properties of wheat flour. Cereal Chemistry 75, 222-229.

Horiuchi, T., Fukishima, D., Sugimoto, H. Hattori, T. (1978). Studies on enzyme-modified proteins as foaming agents: effect of structure on foam stability. Food Chemistry 3, 35-42.

Husband, F.A., Wilde, P.J., Mackie, A.R., Garrood, M.J. (1997). A comparison of the functional and interfacial properties of $\beta$-casein and dephosphorylated $\beta$-casein. Journal of Colloid and Interface Science, 195, 77-85.

Krägel, J., Wüstneck, R., Clark, D.C., Wilde, P.J., Miller, R. (1995). Dynamic surface tension and surface shear rheology studies of mixed $\beta$-lactoglobulin/Tween 20 systems. Colloids and Surfaces, 98, 127-135.

Kim, S.H., Kinsella, J.E. (1985). Surface activity of food proteins: relationships between surface pressure development, viscoelasticity of interfacial films and foam stability of bovine serum albumin. Journal of Food Science, 50, 1526-1530.

Kooijman, M., Orsel, R., Hessing, M., Hamer, R.J., Bekkers, A.C.A.P.A. (1997). Spectroscopic characterisation of the lipid binding properties of wheat puroindolines. Journal of Cereal Science 26, 145-159.

Lorient, D., Closs, B., Courthaudon, J.L. (1989). Surface properties of the bovine casein components: relationships between structure and foaming properties. Journal of Dairy Research 56, 495-502.

Mackie, A. R., Gunning, A. P., Wilde, P. J., Morris, V. J. (1999). The orogenic displacement of protein from the air/water interface by surfactant. Journal of Colloid and Interface Science 210, 157-166.

MacRitchie, F. (1978). Proteins at interfaces. Advances Protein Chemistry, 32, 283-326.

Maeda, K., Yokoi, S., Kamada, K., Kamimura, M. J. (1991). Foam stability and physicochemical properties of beer. American Society of Brewing Chemists 49, 14-18. 
Mitchell, J.R. (1986). Foaming and emulsifying properties of proteins. In Developments in Food Proteins - $4 \mathrm{p}$. 291-338, B.J.F. Hudson (Ed.), Elsevier, London.

Pérez, M.D., Sanchez, L., Aranda, P., Ena, J.M., Oria, R., Calvo, M. (1992). Effect of beta-lactoglobulin on the activity of pregastric lipase. A possible role for this protein in ruminant milk. Biochimica Biophysica Acta 1123, 151-155.

Sorensen, S.B., Bech, L.M., Muldberj, M., Beenfeldt, T., Breddam, K. (1993). Barley lipid transfer protein 1 is involved in beer foam formation. MBAA Tech. Quart. 30, 136-145.

Toledano, O. Magdassi, S. (1988). Emulsification and foaming properties of hydrophobically modified gelatin. Journal of Colloid and Interface Science, 200, 235-240.
Townsend, A., Nakai, S. (1983). Relationships between hydrophobicity and foaming characteristics of food proteins. Journal of Food Science, 48, 588-594.

Watanabe, M., Toyokawa, H., Shimada, A. Arai, S. (1981). Protinaceous surfactants produced from gelatin by enzymatic modification: evaluation for their functionality. Journal of Food Science 46, 1467-1469.

Wilde, P. J. (1996). Foam measurement by the microconductivity technique: an assessment of its sensitivity to interfacial and environmental factors. Journal of Colloid and Interface Science 178, 733-739.

Wilde, P.J., Clark, D.C., Marion, D. (1993). The influence of competitive adsorption of a lysopalmitoyl phosphatidylcholine on the functional properties of puroindoline, a lipid binding protein isolated from wheat flour. Journal of Agricultural and Food Chemistry 41, 1570-1576. 